\title{
Hubungan Pengetahuan Dengan Sikap Remaja Tentang Dampak Aborsi
}

\author{
Hamdayani $^{1}$, Sainah ${ }^{2}$, Muh. Sofyan ${ }^{3}$, Ilham Nur Putri ${ }^{4}$ \\ 1,3,4 Program Studi Ilmu Keperawatan, Universitas Patria Artha \\ ${ }^{2}$ Program Studi Diploma Tiga Kebidanan, Universitas Patria Artha
}

\begin{tabular}{l} 
Info Artikel \\
\hline Riwayat Artikel: \\
Received : 03 Desember 2021 \\
Revised : 20 Desember 2021 \\
Accepted : 28 Desember 2021 \\
\hline
\end{tabular}

\section{Kata Kunci:}

Aborsi

Pengetahuan

Sikap

\begin{abstract}
ABSTRAK
Aborsi yang marak dilakukan saat ini bukan berdasarkan pada aturan sesuai undang-undang kesehatan namun dilakukan menyimpang dari aturan tersebut sehingga aborsi yang terjadi tidak terlepas dari pergaulan remaja saat ini yang sangat memprihatinkan adalah karena banyak remaja melakukan seks bebas dan hamil diluar nikah, tidak sedikit dari mereka memilih melakukan aborsi karena merupakan aib bagi keluarga.Tujuan penelitian ini adalah menganalisis pengetahuan dan sikap remaja tentang dampak aborsi. Metode penelitian yang digunakan adalah jenis penelitian kuantitatif menggunakan rancangan penelitian analitik korelasi dengan pendekatan desain cross sectional study. Populasi dalam penelitian ini adalah siswi yang berada di SMAN 1 Watansoppeng sebanyak 490 siswi, jumlah sampel yang mewakili populasi sebanyak 38 siswi dengan menggunakan teknik purposive sampling. Variabel independen yaitu pengetahuan remaja tentang dampak aborsi dan variabel dependen sikap remaja tentang dampak aborsi kedua variabel menggunakan instrumen berupa angket atau kuesioner. Pengumpulan data dengan memperhatikan etika penelitian. Data diolah dengan menggunakan SPSS for windows versi 21.0. Data dianalisis menggunakan uji data chisquare dengan tingkat signifikansi $\alpha=0,05$, karena data yang diuji tidak memenuhi syarat untuk digunakan uji chi-Square maka peneliti menggunakan uji cadangan yaitu uji kolmogorov smirnov. Berdasarkan hasil analisis uji kolmogorov menunjukkan bahwa ada hubungan antara pengetahuan dengan sikap remaja tentang dampak aborsi dengan nilai $\mathrm{p}=$ $0,03<0,05$. Maka ada hubungan yang signifikan antara pengetahuan dengan sikap remaja tentang dampak aborsi. Implikasi penelitian bahwa masih ada beberapa responden yang pengetahuannya kurang dengan sikapnya tidak baik tentang dampak aborsi.
\end{abstract}

This is an open access article under the CC BY-SA license.

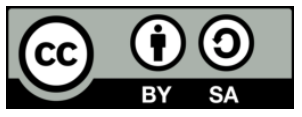

\section{Corresponding Author:}

Hamdayani,

Prodi Ilmu Keperawatan, Fakultas Kesehatan, Universitas Patria Artha,

Jl Tun Abdul Razak, Hertasning Baru Poros Gowa, Makassar, Indonesia.

Email: hamdayaniku1983@gmail.com / Phone: 081241768383

\section{PENDAHULUAN}

Aborsi adalah pengeluaran hasil konsepsi sebelum janin dapat hidup diluar kandungan. Ini adalah suatu proses pengakhiran hidup dari janin sebelum diberi kesempatan untuk bertumbuh. Aborsi yang marak dilakukan saat ini bukan berdasarkan pada aturan sesuai undang-undang kesehatan namun dilakukan menyimpang dari aturan tersebut. Makanya aborsi yang terjadi tidak terlepas dari pergaulan remaja saat ini yang sangat memprihatinkan adalah karena banyak remaja melakukan seks bebas dengan pacarnya. Dan alhasil hamil diluar nikah, tidak sedikit dari mereka memilih melakukan aborsi karena merupakan aib bagi keluarga. Menurut Azinar (2013), ada pengaruh yang signifikan antara akses dan kontak media informasi khususnya media pornografi dengan perilaku seksual pranikah berisiko KTD (Kehamilan Tidak Diinginkan). Tidak sedikit remaja yang memiliki pemikiran bahwa mereka tidak akan hamil jika pertama kali melakukan hubungan seksual dan jika melakukan hubungan seksual tidak sampai klimaks tidak menyebabkan kehamilan di luar nikah (Arisandi, 2012). World Health Organization (WHO) memperkirakan bahwa di seluruh dunia, 
kira-kira 21,6 juta abortus terjadi pada tahun 2008, dan hampir seluruh kasus abortus ini terjadi di wilayah Negara-Negara berkembang (Sedgh, 2011).

Berdasarkan penelitian WHO, sejak awal 2010 hingga kini, di Indonesia diperkirakan ada sekitar 20$60 \%$ kasus aborsi yang disengaja. Penelitian di 10 kota besar dan enam kabupaten di Indonesia juga memperkirakan sekitar 2 juta kasus aborsi, dengan 50\% terjadi di wilayah perkotaan. Data pada tahun 2013 Angka Kematian Ibu (AKI) di Indonesia berjumlah 226 per 100.000 kelahiran hidup, hal ini disebabkan karena perdarahan $42 \%$, abortus $11 \%$ Di Indonesia diperkirakan setiap tahun dilakukan sejuta abortus tidak aman. Data kongkrit yang ditulis oleh Muhammad Faisal dan Sabir Ahmad, menunjukkan bahwa perkiraan setiap tahun di Indonesia terjadi 16,7 sampai dengan 22,2 abortus provokatus perseratus kelahiran hidup (Suryono, 2001). Kasus aborsi menjadi salah satu penyumbang terbesar penyebab kematian di Indonesia sejak beberapa dekade terakhir. Kematian akibat aborsi tersebut mencakup aborsi yang disengaja. Wanita dengan riwayat abortus mempunyai resiko lebih tinggi untuk terjadinya persalinan prematur, abortus berulang, Berat Badan Lahir Rendah (BBLR) (Cunningham, 2010).

Berdasarkan data yang dikeluarkan BKKBN di Indonesia diperkirakan setiap tahun jumlah aborsi mencapai 2,4 juta jiwa dan praktik aborsi di Indonesia cenderung meningkat bahkan trend peningkatannya tiap tahun rata-rata mencapai $15 \%$. Tetapi Indonesia tidak mempunyai angka aborsi secara khusus. Abortus tetap merupakan masalah yang masih kontroversial. Disatu sisi memperbolehkan karena alasan lebih mengutamakan hak ibu sedangkan kelompok lain berpendapat bahwa hak anak untuk hidup yang utama. Legitimasi abortus provokatus di suatu negara sangat tergantung kepada hukum yang berlaku di negara tersebut (Susanti, 2010). Perempuan sebagai korban perkosaan yang kemudian diketahui mengandung janin sebagai akibat perkosaan yang pernah dialaminya, yang pada akhirnya memilih untuk melakukan aborsi (abortus provocatus), dalam ketentuan hukum pidana khususnya melalui Undang-Undang No.36 Tahun 2009 tetap mendapatkan perlindungan hukum sebagaimana yang diatur dalam undang-undang tersebut. Terdapat hubungan yang bermakna secara statistik antara pengetahuan dengan perilaku seksual remaja di SMAN 1 Subang (Rahma, 2018).

Menurut Komnas Perlindungan Anak (Komnas PA) dalam Forum Diskusi Anak Remaja pada tahun 2018, disebutkan bahwa di 12 kota besar di Indonesia, antara lain Jakarta, Bandung, Yogyakarta, Makassar, Medan, Lampung, Palembang, Kepulauan Riau dan kota-kota di Sumatera Barat sekitar 21,2\% remaja pernah melakukan aborsi. Kasus abortus di Sulawesi Selatan dilaporkan bahwa pada periode Januari sampai dengan Desember 2018, kasus abortus ada 3.499 kasus (DINKES SulSel, 2019). Badan pusat statistik Kabupaten Soppeng di tahun 2018, mengeluarkan hasil survey bahwa jumlah penduduk di Kabupaten Soppeng sebanyak 226.466 jiwa yang diantaranya Kecamatan Lalabata memiliki 44.828 jiwa. Angka kematian janin pada kasus aborsi pada remaja di daerah Kabupaten Soppeng tahun 2017 (yang dilaporkan) sebanyak 113 jiwa. Oleh karena itu remaja perlu mengetahui dampak aborsi itu sendiri agar dapat mencegahnya dari dini. (DINKES Soppeng, 2017). Hasil survey awal pada 12 siswi masih banyak siswi kurang memahami tentang apa saja penyebab aborsi, seberapa jauh pengetahuan responden tentang aborsi, serta dampak kedepannya seperti apa bagi responden itu sendiri. sehingga hal ini yang menjadi pertimbangan awal bagi peneliti untuk meneliti hubungan pengetahuan dengan sikap remaja tentang dampak aborsi. Penelitian ini bertujuan untuk menganalisis hubungan pengetahuan dengan sikap remaja tentang dampak aborsi.

\section{METODE PENELITIAN}

Penelitian ini merupakan penelitian kuantitatif dengan rancangan penelitian analitik korelasi menggunakan pendekatan desain cross sectional study. Variabel independen dalam penelitian ini adalah pengetahuan remaja tentang dampak aborsi sedangkan variabel dependen pada penelitian ini adalah sikap remaja tentang dampak aborsi. Penelitian ini dilakukan di SMAN 1 Watansoppeng, Kelurahan Botto, Kecamatan Lalabata, Kabupaten Soppeng. Populasi dalam penelitian ini adalah seluruh siswi yang berada di SMAN 1 Watansoppeng sebanyak 490 siswi. Sampel adalah sebagian dari jumlah dan karakteristik yang dimiliki oleh populasi (Sogiyono, 2012). Dapat disimpulkan sampel adalah sebagian yang diambil dari keseluruhan objek yang akan diteliti dan dianggap mewakili seluruh populasi. Pemilihan sampel dalam penelitian ini menggunakan teknik purposive sampling dengan kriteria inklusi yaitu siswi yang duduk di kelas XII MIA 4 dan 5, Siswi yang hadir pada saat dilakukan penelitian, siswi yang bersedia menjadi responden sedangkan kriteria eksklusi yaitu siswi yang tidak kooperatif. Jumlah sampel dalam penelitian ini adalah sebanyak 38 siswi. Instrumen dalam mengumpulkan data yang digunakan peneliti dalam penelitian ini adalah kuesioner. Untuk variabel independen yaitu pengetahuan remaja tentang dampak aborsi menggunakan instrumen kuesioner dengan pengukuran skala guttman pada variabel pengetahuan yaitu $\mathrm{Ya}=1$, Tidak=0, dengan 10 item pertanyaan sedangkan untuk variabel dependen yaitu sikap remaja tentang dampak aborsi menggunakan kuesioner dengan pengukuran skala likert pada variabel sikap yaitu $\mathrm{TS}=1, \mathrm{KS}=2, \mathrm{~S}=3, \mathrm{SS}=$ 4 dengan 10 item pernyataan. Pengumpulan data tetap memperhatikan etika penelitian seperti informed consent, confidentiality, justice, respect for person, beneficence dan nonmaleficence. Jenis data yang 
dikumpulkan yaitu data primer dan sekunder. Pengolahan data diolah dan dianalisis dengan menggunakan SPSS for windows versi 21.0. Teknik analisis data dalam penelitian ini yaitu menggunakan uji kolmogorov smirnov dengan tingkat kemaknaan $\mathrm{p} \leq 0,05$, dapat disimpulkan ada hubungan antara variabel pengetahuan dengan sikap remaja tentang dampak aborsi, demikian pula sebaliknya bila nilai $\mathrm{p}>0,05$, dapat disimpulkan tidak ada hubungan antara variabel pengetahuan dengan sikap remaja tentang dampak aborsi.

\section{HASIL}

\subsection{Karakteristik Demografi Responden}

Tabel 1. Karakteristik Responden

\begin{tabular}{lcc}
\hline Karakteristik & Frekuensi $(f)$ & Persentase $(\%)$ \\
\hline Umur & 25 & 65,8 \\
17 Tahun & 13 & 34,2 \\
18 Tahun & $\mathbf{3 8}$ & $\mathbf{1 0 0 , 0}$ \\
\hline Total & & 60,5 \\
\hline Agama & 23 & 38,5 \\
Islam & 15 & $\mathbf{1 0 0}$ \\
Kristen & $\mathbf{3 8}$ &
\end{tabular}

Tabel 1 diatas memperlihatkan dari 38 responden yang diteliti dengan melihat frekuensi yang diatas peneliti menemukan bahwa kelompok umur terbanyak adalah 17 tahun yaitu sebanyak $25(65,8 \%)$ dan kelompok umur paling sedikit adalah 18 tahun yaitu sebanyak 13 (34,2\%). Sedangkan kelompok agama terbanyak adalah Islam yaitu sebanyak $23(60,5 \%)$ dan kelompok agama paling sedikit adalah kristen yaitu sebanyak $15(39,5 \%)$.

\subsection{Analisis Univariat}

Tabel 2. Distribusi Frekuensi Responden Berdasarkan Tingkat Pengetahuan

\begin{tabular}{ccc}
\hline Tingkat Pengetahuan & Frekuensi $(\boldsymbol{f})$ & Persentase $(\%)$ \\
\hline Baik & 5 & 13,2 \\
Cukup & 1 & 2,6 \\
Kurang & 32 & 84,2 \\
\hline Total & $\mathbf{3 8}$ & $\mathbf{1 0 0 , 0}$ \\
\hline
\end{tabular}

Tabel 2 diatas memperlihatkan dari 38 responden yang diteliti diperoleh data jumlah responden dengan distribusi tertinggi sebanyak 32 responden $(84,2 \%)$ memiliki tingkat pengetahuan kurang, sedangkan distribusi terendah sebanyak 1 responden $(2,6 \%)$ memiliki tingkat pengetahuan cukup.

Tabel 3. Distribusi Frekuensi Responden Berdasarkan Sikap

\begin{tabular}{ccc}
\hline Sikap & Frekuensi $(\boldsymbol{f})$ & Persentase $(\boldsymbol{\%})$ \\
\hline Baik & 12 & 31,6 \\
Tidak baik & 26 & 68,4 \\
\hline Total & $\mathbf{3 8}$ & $\mathbf{1 0 0 , 0}$ \\
\hline
\end{tabular}

Tabel 3 diatas memperlihatkan dari 38 responden yang diteliti diperoleh data responden memiliki sikap baik sebanyak 12 responden $(31,6 \%)$ sedangkan yang memiliki sikap tidak baik sebanyak 26 responden $(68,4 \%)$. 


\subsection{Analisis Bivariat}

Tabel 4. Hubungan pengetahuan dengan sikap remaja tentang dampak aborsi

\begin{tabular}{|c|c|c|c|c|c|c|c|}
\hline \multirow{3}{*}{ Pengetahuan } & \multicolumn{6}{|c|}{ Sikap } & \multirow{3}{*}{$p$} \\
\hline & \multicolumn{2}{|c|}{ Baik } & \multicolumn{2}{|c|}{ Tidak Baik } & \multicolumn{2}{|c|}{ Total } & \\
\hline & $\mathrm{n}$ & $\%$ & $\mathrm{n}$ & $\%$ & $\mathrm{n}$ & $\%$ & \\
\hline Baik & 5 & 13,2 & 0 & 0 & 5 & 13,2 & \multirow{4}{*}{0,003} \\
\hline Cukup & 1 & 2,6 & 0 & 0 & 1 & 2,6 & \\
\hline Kurang & 6 & 15,8 & 26 & 68,4 & 32 & 84,2 & \\
\hline Total & 12 & 31,6 & 26 & 68,4 & 38 & 100 & \\
\hline
\end{tabular}

Tabel 4 diatas memperlihatkan dari 38 responden yang telah diteliti untuk 5 siswi pengetahuan baik dilihat 5 siswi $(13,2 \%)$ yang sikapnya baik kemudian dilihat tidak ada siswi $(0,0 \%)$ yang sikapnya tidak baik, dari 1 siswi pengetahuan cukup terdapat 1 siswi $(2,6 \%)$ yang sikapnya baik kemudian tidak ada $(0,0 \%)$ yang sikapnya tidak baik dan 32 siswi $(84,2 \%)$ pengetahuan kurang terdapat 6 siswi $(15,8 \%)$ sikapnya baik kemudian 26 siswi $(68,4 \%)$ yang sikapnya tidak baik.

\section{DISKUSI}

Hasil penelitian ini adalah terdapat hubungan yang signifikan antara pengetahuan dengan sikap remaja tentang dampak aborsi. Berdasarkan pengetahuan remaja tentang dampak aborsi pada tabel 2 dari 38 responden yang diteliti diperoleh data jumlah responden dengan distribusi tertinggi sebanyak 32 responden $(84,2 \%)$ memiliki tingkat pengetahuan kurang, hal ini didasari dengan kurang perhatian dari lembaga pendidikan dan keagamaan. Sejalan dengan penelitian Eko (2013), kurang pemahaman tentang risiko aborsi pada remaja maka cenderung akan mendekati aborsi sedangkan distribusi terendah sebanyak 1 responden $(2,6 \%)$ memiliki tingkat pengetahuan cukup. Menurut Notoatmodjo (2003), pengetahuan adalah hasil dari system indra yang dimiliki manusia (penglihatan, pendengaran, dan penciuman) dan hasil tahu oleh individu terhadap suatu objek tertentu. Pengetahuan adalah suatu keadaan atau kondisi yang ditemui atau diperoleh seseorang melalui beberapa alat indra seperti penglihatan, dengan adanya alat indra maka seseorang dapat memperoleh pengetahuan yang ada.

Berdasarkan sikap remaja tentang dampak aborsi pada data tabel 3 dari 38 responden yang diteliti diperoleh data responden memiliki sikap baik sebanyak 12 responden $(31,6 \%)$ sedangkan yang memiliki sikap tidak baik sebanyak 26 responden $(68,4 \%)$. Hal ini didasari oleh keadaan sosial dan pergaulan siswi cenderung akan mendekati aborsi karena kurangnya pemahaman tentang dampak aborsi. Hal ini sejalan dengan teori sikap menurut Notoatmodjo (2003) sikap merupakan reaksi pada individu terhadap stimulus yang berkaitan dengan ketersediaan individu dalam melakukan sesuatu yang baik maupun tidak baik, senang maupun tidak senang. Sejalan dengan penelitian yang telah dilakukan oleh Ayu \& Kurniawati (2017) menemukan bahwa ada hubungan antara sikap remaja terhadap aborsi.

Berdasarkan hasil penelitian hubungan pengetahuan dengan sikap remaja tentang dampak aborsi pada data tabel 4 dari 38 responden didapatkan hasil 5 siswi $(13,2 \%)$ yang memiliki pengetahuan baik dengan tingkat sikap yang baik, pengetahuan baik dengan tingkat sikap yang tidak baik sebanyak 0 siswi $(0,0 \%)$ dan pengetahuan cukup dengan tingkat pengetahuan baik sebanyak 1 siswi $(2,6 \%)$, hal ini didasari dengan pendidikan yang lebih memadai yang dimiliki oleh para siswi. Sejalan dengan penelitian Yusrizarni (2013) salah satu solusi mengatasi pergaulan bebas adalah memberi upaya promotif. Dari 32 siswi $(84,2 \%)$ pengetahuan kurang terdapat 6 siswi $(15,8 \%)$ sikapnya baik kemudian 26 siswi $(68,4 \%)$ yang sikapnya tidak baik, hal ini dipengaruhi karena kurang perhatian dari lembaga pendidikan dan lembaga keagamaan sebagai peletakan pengertian dasar, pemahaman akan baik dan buruk, dan konsep moral dalam diri individu.

Berdasarkan hasil uji statistik kolmogorov diperoleh nilai $p=0,03$ yang berarti lebih kecil dari nilai $\alpha=$ 0,05 bahwa ada hubungan yang signifikan antara pengetahuan dengan sikap remaja tentang dampak aborsi di SMAN 1 Watansoppeng. Pada hasil penelitian terdahulu menurut Maesaro \& Nur (2018) menemukan bahwa ada hubungan tingkat pengetahuan remaja tentang dampak abortus provokatus kriminalis. Sejalan dengan penelitian yang telah dilakukan oleh Endah (2018) diperoleh hasil penelitian pengetahuan remaja tentang penyebab dan akibat kehamilan dini sebagian besar responden adalah tidak tahu 25 responden $(51,0 \%)$ pada siswi kelas XI IPA di SMAN 1 Mayong Jepara. Berdasarkan penelitian yang dilaksanakan oleh (Fathikah and Santosa, 2016) bahwa sikap siswi SMAN 1 Sliyeg terhadap abortus sekitar 76,41\% tidak setuju terhadap hamil di luar nikah dan melakukan aborsi. Berdasarkan penelitian yang dilaksanakan oleh Nasihah (2016), diketahui terdapat sebagian besar sikap remaja putri di Madrasah Aliyah Negeri Lamongan dapat diberi bimbingan tentang kesehatan reproduksi. Hal ini sejalan dengan hasil penelitian yang dilakukan oleh 
Yusrizarni (2013), tentang hubungan pengetahuan dan sikap siswi terhadap aborsi di SMA Negeri 2 Darul Makmur Aceh Barat. Didapatkan $p$ value $=0.001<0,005$ artinya ada hubungan yang signifikan antara pengetahuan siswi terhadap aborsi. Hal ini sejalan dengan hasil penelitian yang dilakukan oleh Mariza (2009), bahwa terdapat hubungan yang sangat erat antara tingkat pengetahuan dengan sikap pengambilan keputusan untuk aborsi di SMK Muhammadiyah IV Yogyakarta. Berdasarkan hasil akhir dari uji statistik yang dilakukan pada penelitian Musvita \& Kurniawati (2017) didapatkan adanya hubungan antara tingkat pengetahuan remaja putri tentang aborsi dengan sikap remaja terhadap aborsi pada siswi MAN 2 Kediri Jawa Timur tentang aborsi, ditunjukkan hasil uji chi square diperoleh $\mathrm{p}$ value $0,027<0,05$.

Maka dari penelitian ini disimpulkan sebagian besar siswi memiliki sikap tidak baik didasari oleh pengetahuan dan begitu pula sebaliknya sikap yang tidak baik didasari oleh pengetahuan yang kurang. Sehingga dari penelitian ini dapat disimpulkan bahwa terdapat hubungan antara pengetahuan dengan sikap remaja tentang dampak dari aborsi.

\section{KESIMPULAN}

Berdasarkan hasil penelitian yang dilakukan, hubungan pengetahuan dengan sikap remaja tentang dampak aborsi, didapatkan bahwa $\mathrm{p}$ value $=0,003<0,05$ artinya ada hubungan yang signifikan antara pengetahuan dengan sikap remaja tentang dampak aborsi di SMAN 1 Watansoppeng. Untuk itu berdasarkan hasil penelitian dan teori yang ditemukan maka dapat dilihat betapa pentingnya pengetahuan dengan sikap bagi siswi tentang dampak aborsi. Untuk itu perlu adanya upaya dalam mengatasi dampak aborsi. Penulis berasumsi bahwa salah satu hal yang mempengaruhi pengetahuan dengan sikap remaja tentang dampak aborsi adalah kurangnya informasi dan edukasi dini. Sehingga diharapkan bagi pihak sekolah untuk melaksanakan kegiatan penyuluhan kesehatan berkelanjutan tentang dampak yang ditimbulkan apabila melakukan aborsi.

\section{REFERENSI}

Arisandi. (2012). Sikap Terhadap Aborsi Pada Mahasiswa Universitas Esa Unggul, Jurnal psikologi: Media Ilmiah Psikologi, 10 (01), 27-30.

Cunningham, F., G. (2010). Obstetri. Jakarta: EGC.

Dinkes Soppeng. (2017). Profil Kesehatan Sulawesi Selatan 2017. Soppeng.

Dinkes SulSel. (2019). Profil Kesehatan Sulawesi Selatan 2019. Makassar.

Eko, N. (2013). Hubungan Pengetahuan Remaja Tentang Risiko Aborsi Dengan Sikap Remaja Terhadap Seks Pranikah Di Sma Negri 1 Sewon Bantul, Available at: http://repository.unjaya.ac.id/2653/1/Eko Nurwanto_3208047_nonfull.pdf.

Suryono, E. (2001). Abortus Provokatus Bagi Korban Perkosaan Perspektif Viktimologi, Kriminologi dan Hukum Pidana. 1st edn. Yogyakarta: Universitas Atma Jaya.

Endah. (2018). Pengetahuan Remaja Tentang Aborsi Akibat Kehamilan Usia Dini Pada Siswi di SMA N 1 Mayong Jepara, Jurnal Kebidanan dan Kesehatan, 8(1), 12-24

Fathikah, T. and Santosa, S. (2016). Gambaran Pengetahuan,Sikap, dan Perilaku Remaja Terhadap Abortus Provocatus Di SMA N 1 Sliyeg Kabupaten Indramayu, Jurnal Kedokteran Diponegoro, 5(3), 235-245. doi: https://doi.org/10.14710/dmj.v5i3.13094.

Maesaro, S. and Fauziah Ani Nur. (2018). Pengetahuan Remaja Putri Tentang Resiko Tindakan Aborsi Terhadap Kesehatan dan Hukum, Jurnal Kebidanan Indonesia, 9(1). doi: https://doi.org/10.36419/jkebin.v9i1.134.

Mariza. (2009). Hubungan Tingkat Pengetahuan Remaja Putri tentang Abortus Dengan Sikap Pengambilan Keputusan Untuk Aborsi di SMK Muhammadiyah IV Yogyakarta. Available at: https://123dok.com/document/zlegn2lqhubungan-pengetahuan-tentang-abortus-pengambilan-keputusan-muhammadiyah-yogyakarta.html.

Musvita Ayu, S. and Kurniawati, T. (2017). Hubungan Tingkat Pengetahuan Remaja Putri Tentang Aborsi Dengan Sikap Remaja Terhadap Aborsi Di Man 2 Kediri Jawa Timur, Unnes Journal of Public Health (UJPH), 6(2). doi: https://doi.org/10.15294/ujph.v6i2.13736.

Nasihah, M. (2016). Gambaran Pengetahuan Dan Sikap Remaja Putri Terhadap Aborsi, Jurnal kebidanan, 8(1). doi: https://doi.org/10.30736/midpro.v8i1.4.

Notoatmodjo. (2003). Pendidikan dan Perilaku Kesehatan. Jakarta: Rineka Cipta.

Rahma, M. (2018). Hubungan antara pengetahuan seksualitas dengan perilaku seksual remaja di SMA N 1 Subang. Ikatan Bidan Indonesia, 5(1).

Sedgh, G. (2011). Legal Abortion Worldwide in 2008: Levels and Recent Trends, International Perspectives on Sexual and Reproductive Health, 37(2), 84-94. doi: 10.1363/3708411.

Sogiyono (2012) Metode Penelitian Kuantitatif Kualitatif. Bandung: CV Alfabeta.

Susanti, R. (2010). Payung Hukum Pelaksaan Abortus Provokatus Pada Kehamilan Akibat Perkosaan, Majalah Kedokteran Andalas, 34(1). doi: https://doi.org/10.22338/mka.v34.i1.p25-30.2010.

Yusrizarni. (2013). Hubungan Pengetahuan Dengan sikap siswa/i Terhadap Aborsi di SMA N 2 Darul Makmur Kabupaten Nagan Raya 